\title{
TRADISI TURUN MANDI DI DUSUN PENGHIJAUAN DESA PASAR BARU KECAMATAN PANGEAN KABUPATEN KUANTAN SINGINGI RIAU
}

\author{
Ika Mar Isla ${ }^{*}$, Siti Fatimah ${ }^{2 *}$ \\ Program Studi Pendidikan Ilmu Pengetahuan Sosial Konsentrasi Pendidikan Seni dan Budaya \\ Program Pascasarjana \\ Universitas Negeri Padang \\ Jl. Prof. Dr. Hamta, Air Tawar Padang, Kel. Air Tawar Barat, Kec. Padang Utara, Kota Padang, Kode Pos 25171 \\ Sumatera Barat. Indonesia \\ Email: ikamarisla.hs@gmail.com
}

\begin{abstract}
Abstrak
Tradisi bacungak atau turun mandi ini adalah sebuah tradisi yang dilakukan oleh masyarakat pangean untuk meresmikan seorang bayi yang baru lahir agar bisa mandi kesungai dan keluar rumah dengan "bebas". Tujuan dari penelitian ini adalah untuk pertama-tama mengetahui tradisi mandi di desa penghijauan. Tujuan kedua adalah untuk mengetahui apa saja peralatan dan prosedur untuk melaksanakan tradisi mandi di desa penghijauan. Tujuan ketiga adalah untuk mengetahui kearifan lokal dari dusun Penghijauan. Penelitian ini menggunakan pendekatan kualitatif dengan metode deskriptif. Pengumpulan data dilakukan dengan observasi, wawancara, dokumentasi dan studi literatur. Berdasarkan temuan penelitian, terlihat bahwa orang-orang di dusun penghijauan masih mengangkat dan menjalankan tradisi turun mandi meskipun ada perubahan yang terjadi, yaitu tempat prosesi pelaksanaan di mana tradisi turun mandi dulu dilakukan di sungai tetapi sekarang sungai telah tercemar dan tidak lagi cocok digunakan untuk melaksanakan tradisi mandi. Karena itu, orang sekarang menjalankan tradisi mandi di rumah mereka dan tradisi bacungak ini salah satu kearifan lokal dari masyarakat dusun penghijauan.
\end{abstract}

Kata Kunci: tradisi turun mandi, kuantan singingi.

\begin{abstract}
This tradition of bacungak or bathing is a tradition carried out by the Pangean society to inaugurate a newborn baby in order to take a bath in the river and leave the house "freely". The purpose of this study is to first find out the tradition of bathing in the Penghijauan village. The second objective is to find out what equipment and procedures to carry out the tradition of bathing in the Penghijauan village. The third objective is to find out the local wisdom of the Penghijauan Village. This research uses a qualitative approach with descriptive methods. Data collection is done by observation, interviews, documentation and literature studies. Based on the research findings, it appears that people in the greening village still adopt and carry out the tradition of bathing despite changes that occur, namely the place of the procession where the tradition of bathing was done in the river but now the river has been polluted and is no longer suitable to carry out bathing traditions. Because of this, people now carry out the tradition of bathing in their homes and this tradition is one of the local wisdoms of the people in greening villages. .
\end{abstract}

Keywords: tradition of bathing, kuantan singingi.

\section{PENDAHULUAN}

Pangean adalah suatu kecamatan yang berada di wilayah Kabupaten Kuantan Singingi Propinsi Riau. Pada awal era otonomi daerah, Pangean merupakan sebuah kecamatan hasil pemekaran dari Kecamatan Kuantan Hilir. Satu hal yang tak bisa dipisahkan dengan Pangean adalah "Silat Pangean". Silat pangean merupakan sebuah seni bela diri yang lahir dan dipopulerkan secara turun temurun oleh guru-guru besar silat pangean (yang biasa dikenal dengan Induak Barompek) zaman dahulu, seni beladiri yang dikenal dengan gerakannya yang lembut dan gemulai namun menyimpan akibat yang mematikan ini telah tersohor keseantero pelosok negeri baik didalam maupun diluar Propinsi Riau.

Tradisi merupakan perbuatan yang dilakukan berulangulang dalam bentuk yang sama. Dalam kamus bahasa indonesia tradisi adalah adat kebiasaan turun-temurun (dari nenek moyang) yang masih dijalankan dalam masyarakat. Selain silat pangean ada juga tradisi yang tidak bisa dipisahkan dengan pangean yaitu tradisi turun mandi. Tradisi turun mandi atau dalam bahasa lain disebut "bacungak" ini sudah menjadi sebuah tradisi yang turun temurun dilakukan kepada bayi yang baru lahir. Sebelum sang bayi ini dimandikan oleh 
dukun beranak (yang istilahnya dukun kampung) ada banyak hal yang mesti dipersiapkan dan diperhitungkan, pertama adalah hari pelaksanaan turun mandi. Sehari sebelum pelaksanaan prosesi turun mandi tersebut hal-hal yang mesti dipersiapkan oleh tuan rumah (orang tua sang bayi) berupa Karambial Satali (2 buah kelapa yang belum dikupas kulitnya dan diambil sedikit kulitnya dan diikat satu sama lain), sakampial bore (beras yang dimasukkan kedalam kantong yang terbuat dari daun pandan kering), satu ekor ayam toge (maksudnya disini adalah bukan sejenis makanan, tetapi seekor ayam kampung yang beratnya sekitar 7-9 ons), limau mandi (buah jeruk purut yang direbus bersama dengan akar bunga siak-siak, sejenis bunga hutan yang mempunya akar yang wangi), katupek (ketupat yang terbuat dari beras pulut), satu buah cermin kecil, sisir, bedak dan minyak kelapa. Prosesi turun mandi sangat penting bagi bayi yang baru lahir hal ini bertujuan untuk membantu bayi tersebut beradaptasi terhadap lingkungan sekitar. Hal ini tidak terlepas dari tingginya tingkat kepercayaan masyarakat terhadap hal-hal mistis yang akan menggangu pertumbuhan dan perkembangan bayi. Sehingga prosesi turun mandi dijadikan sebagai prosesi yang membentengi bayi terhadap hal-hal mistis tersebut.

\section{KAJIAN TEORI}

\section{Teori Antropologi Kebudayaan}

Menurut ilmu antropologi kebudayaan adalah keseluruhan sistem gagasan, tindakan dan hasil karya manusia dalam kehidupan masyarakat yang dijadikan milik diri manusia dengan belajar. Hampir seluruh tindakan manusia adalah kebudayaan karena hanya sedikit tindakan manusia dalam kehidupan masyarakat yang tidak perlu dibiasakan dengan belajar yaitu hanya beberapa tindakan naluri, beberapa reflex, beberapa tindakan manusia yang merupakan kemampuan naluri yang terbawa bersama gen kelahirannya. (Koentjaningrat, 2009:144-145).

Kebudayaan adalah seluruh sistem gagasan dan rasa, tindakan, serta karya yang dihasilkan manusia dalam kehidupan bermasyarakat, yang dijadikan miliknya dengan belajar. Dengan demikian hampir semua tindakan manusia adalah "kebudayaan", karena jumlah tindakan yang dilakukan nya dalam kehidupan bermasyarakat yang tidak dibiasakannya dengan belajar (yaitu tindakan naluri, refleksi, atau tindakantindakan yang dilakukan akibat suatu proses fisiologi, maupun berbagai tindakan membabi buta), sangat terbatas (Koentjaraningrat 2010:72).
Kebudayaan muncul dan berkembang dalam masyarakat Indonesia secara bertahap, Kebudayaan merupakan hasil dari sebuah proses:

Pertama: perkembangan, karena hubungan manusia dan lingkungan alamnya. Hubungan ini mengharuskan manusia ini menyesuaikan diri dengan lingkungan nya secara aktif sepanjang waktu sehingga tercipta kebudayaan,

Kedua: perkembangan karena kemampuan berfikir manusia, dengan hal ini manusia mengolah arti lambang-lambang dalam sistem lambang arti yang berkembang sehingga lepas dari pengertian semula.

\section{Teori Tradisi}

Menurut UU. Hamidy (2009:21-22). Mengatakan Tradisional dalam arti serangkaian kebiasaan dan nilainilai yang diwariskan dari salah satu generasi ke generasi berikutnya, hampir meliputi semua kehidupan masyarakat tertentu. Keberadaan manusia di dunia ini merupakan lingkaran karena itu terangkailah 3 peristiwa penting kehidupan yaitu kelahiran, nikah kawin dan kematian. Dimana tiap peristiwa kehidupan biasanya telah berlangsung dengan suatu upacara, setiap upacara meliputi : (1) waktu, (2) tempat atau ruang, (3) peralatan, (4) teks/pesan upacara, (5) pelaku upacara, (6) peserta upacara. Dengan demikian suatu tradisi yang selalu mngambil bagian dalam rentangan hidup manusia.

Tradisi brasal dari kata latin tradition yang berkata dasar trodere, artinya menyerahkan, meneruskan turun temurun. Tradisi bisa diartikan secara diakronik maupun sinkronik. Pendekatan pertama cendrung membawa kita pada pengertian mengenai tradisi sebagai nilai-nilai kontinyu dari masa lalu yang dipertentangkan dengan modernitas yang penuh perubahan (Laksono, 2009:10). Dikutip dari tesis Shella Marcelina.

Dari kutipan diatas dapat disimpulkan bahwa tradisi itu adalah sesuatu yang dilakukan oleh sekelompok masyarakat dan akan terus di lestarikan dengan cara memperkenalkan kepada generasi-generasi berikutnya supaya para generasi tidak tabu dan paham dengan tradisi yang sudah ada. Hal ini sejalan dengan pendapat Bahar (2011:17) yang mengatakan tradisi merupakan sesuatu yang bersifat 'diteruskan' atau 'ditularkan' dari masa lampau ke masa kini karena hal tersebut patut dicontoh dan dipelihara. (Dikutip dari tesis Shella Marcelina). 


\section{METODE PENELITIAN}

Dalam penelitian ini teknik penulisan data yang digunakan adalah pendekatan kualitatif dan metode deskriptif karena peneliti melakukan penelitian dengan mengkaji ulang bertanya pada orang lain. Menghimpun informasi dan terakhir menarik kesimpulan dari hasil penelitian. Peneliti juga melihat bahwa dengan menggunakan metode kualitatif banyak kelebihan didalamnya maka dari itu peneliti menggunakan metode tersebut. Kelebihan-kelebihan dari metode tersebut adalah : pendekatan kualitatif (induktif) dapat dilakukan dengan cara simultan dan saling mengisi sesuai dengan kebutuhan, sehingga diperoleh suatu proses penelitian dengan ciri utuh dan lengkap. Peneliti berinteraksi dengan subjek yang diteliti, proses penelitiannya bersifat induktif, peneliti menjadi bagian dari subjek penelitian, pemahaman dan penjelasan secara empati. Pendekatan penelitian kualitatif dilakukan secara siklus dan melingkar, bukan proses linear.

\section{HASIL DAN PEMBAHASAN}

\section{Hasil}

\section{1). Kearifan Lokal}

Giddeon dan keraf dalam Daryusti (2010:9) mengatakan kearifan lokal adalah : Kearifan lokal milik kelompok, komunitas atau kolektifitas tertentu yang melokal. Hal ini sejalan dengan proses perkembangan nya, yakni bersumberkan pada pengetahuan pengalaman dalam konteks ruang dimana mereka berada Kearifan lokal merumuskan sesuatu yang diasumsikan benar, karena teruji lewat pengalaman secara kontiniu, karena itu, tidak diperlukan kebenaran alternatif maupun kekritisannya pada saat melaksanakan. Kearifan lokal bersifat praktis, karena dia tidak saja merupakan pembendaharaan kognisi, tetapi terkait pula dengan aspek psikomotorik, yakni praktek dalam kehidupan masyarakat lokal. Label lokal yang melekat pada kearifan lokal, menandakan bahwa secara substantif, dia terkait dengan suatu lokalitas. Hal ini bermakna pula bahwa ketepatgunaan kearifan lokal secara universal. Kearifan lokal tidak saja mencakup aspek praktis, tetapi juga tata kelakuan. Karena itu, pengaktualisasian kearifan lokal pada dasarnya merupakan aktivitas moral. Kearifan lokal bersifat holistik, karena menyangkut pengetahuan dan pemahaman tentang seluruh kehiduan dengan segala relasinya di alam semesta.

Kearifan lokal seringkali ada penjaganya yakni orang bijak, pemimpin agama, atau guru. Karena itulah kearifan lokal tahan lama atau bisa mentradisi. Penjaganya bukan orang ahli (tidak memiliki model intelektual dan model simbolik), tetapi mereka bisa menduduki posisi sebagai penjaga tradisi, karena mampu menafsirkan makna tradisi, baik makna implisit dan ekspilisit sehingga warga komunitas bisa memahami dan mempraktekkannya secara baik dan benar. Kearifan sering terkait dan atau menyatu dengan ajaran maupun praktek-praktek keagamaan misalnya ritual sehingga menambah daya kebertahannya. Kearifan lokal dapat menghidupkan kembali tentang identitas lokal, karena lokal merupakan unsur yang tidak dapat dipisahkan dari kebudayaan sebagai warisan masa lalu. Kearifan lokal terdiri dari dua kata, yaitu kearifan \& lokal. Kearifan berarti kebijaksanaan dan kecendikiawan. Lokal berarti berlaku di suatu tempat. Jika diartikan secara harfiah kearifan lokal berarti kebijaksanaan yang berlaku di suatu tempat. Kata kearifan jika dimengerti secara luas adalah gagasan dan fikiran terhadap norma dan nilai budaya dari masyarakat atau sub bangsa. Dari penjelasan di atas dapat saya simpulkan bahwa kearifan lokal di dusun penghijauan desa pasar baru kecamatan pangean kabupaten kuantan singing adalah norma-norma yang masih di laksanakan seccara turun temurun dan masih mendara daging di kalangan masyarakat setempat.

\section{2).Pelaksanaan Tradisi Turun Mandi dan Perlengkapan yang Digunakan}

Prosesi turun mandi sangat penting bagi bayi yang baru lahir hal ini bertujuan untuk membantu bayi tersebut beradaptasi terhadap lingkungan sekitar. Prosesi turun mandi sangat penting bagi bayi yang baru lahir hal ini bertujuan untuk membantu bayi dapat beradaptasi dengan lingkungan sekitar. Hal ini tidak terlepas dari tingginya tingkat kepercayaan masyarakat terhadap hal-hal mistis yang akan menggangu pertumbuhan dan perkembangan bayi. Prosesi turun mandi dijadikan sebagai prosesi yang membentengi dan menguatkan bayi terhadap hal-hal mistis tersebut.

Sebelum bayi ini dimandikan oleh dukun beranak atau dikenal dengan istilah (dukun kampong) dan pelaksanaan prosesi akikah berlangsung, ada beberapa hal yang mesti dipersiapkan ketika melaksanakan acara turun mandi dan prosesi akikah ini, pertama adalah hari pelaksanaan turun mandi. jika bayi laki-laki maka acara turun mandinya dilaksanakan pada hari ganjil yaitu hari ke 1,3, 5, 7, 9, 11, dan seterusnya dari hari kelahiran sang bayi, dan jika bayinya perempuan maka hari turun mandinya hari genap seperti hari ke 2, 4, 6, 8, 10, 12 dan seterusnya. Penentuan hari pelaksanaan tersebut tergantung pada kesiapan dan tali pusat sang bayi sudah lepas.

Sehari sebelum pelaksanaan prosesi turun mandi dan prosesi akikah tersebut hal-hal yang mesti dipersiapkan 


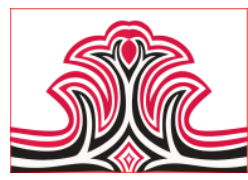

oleh tuan rumah (orang tua sang bayi) berupa Karambial Satali (2 buah kelapa yang belum dikupas kulitnya dan diambil sedikit kulitnya dan diikat satu sama lain), sakampial bore (beras yang dimasukkan kedalam kantong yang terbuat dari daun pandan kering), satu ekor ayam toge (maksudnya disini adalah bukan sejenis makanan, tetapi seekor ayam kampung yang beratnya sekitar 7-9 ons), limau mandi (buah jeruk purut yang direbus bersama dengan akar bunga siak-siak, sejenis bunga hutan yang mempunya akar yang wangi), katupek (ketupat yang terbuat dari beras pulut), satu buah cermin kecil, sisir, bedak dan minyak kelapa, sedangkan prosesi akikah hal-hal yang mesti di persiapkan adalah penyembelihan dua ekor kambing jikalau ayak laki-laki, penyembelihan satu ekor kambing jikalau anak perempuan.

Setelah semua bahan dipersiapkan maka sang dukun bayi memulai prosesi turun mandi yang dimulai dengan memberikan/memasang colak (colak terbuat dari ramuan arang kayu dan jaring laba-laba yang berwarna hitam pekat) kepada bayi yang telah dia persiapkan sebelumnya dari rumah dengan

menggunakan kuas bulu ayam, ini dipasang ke alis mata sang bayi dengan disertai mantera-mantera, Setelah itu sang bayi dan ibunya dibawa keluar rumah menuju sungai Batang Kuantan /tempat pemandian, sang dukun yang menggendong bayi tersebut menggunakan payung dan memegang parasopan (puntung kayu yang di bakar) yang diiringi dengan rarak calempong (musik tradisional), bayi ini terlebih dahulu dibawa bersilat di halaman rumah oleh sang dukun sebelum menuju sungai dan diringi dengan membawa bintang limau (semua peralatan turun mandi di kumpulkan pada satu tempat/ wadah) dan ayam toge (seekor ayam kampung yang memiliki berat 7-9 ons ), Sesampainya di tepian sungai, sang dukun bayi memulai prosesi turun mandi ini dengan beragam cara:

- Mempersiapkan bintang limau (alat-alat serta perlengkapan untuk tradisi turun mandi).

- sebelum mandi ke sungai sang bayi ini dipasangkan colak yang terbuat dari ramuan arang kayu dan sarang laba-laba.

- $\quad$ si bayi menduduki ayam yang di apit oleh kedua paha sang ibu dan dukun menyiram kan air limau mandi ke atas kepala sang ibu.

- Menghanyutkan bara kayu ke sungai.

- menghadapkan sang bayi ke cermin setelah dibedaki
Gorga Jurnal Seni Rupa

Volume 08 Nomor 02 Juli-Desember 2019 p-ISSN: 2301-5942 | e-ISSN: 2580-2380

Setelah prosesi turun mandi selesai dilaksanakan, ketupat yang ada didalam bintang limau tadi diperebutkan oleh para penonton. Sesampainya dirumah sang bayi dimasukkan kedalam ayunan yang terlebih dahulu dibuat dengan menggunakan kain sarung yang juga dibawahnya

diletakkan parasopan (asap yang ditimbulkan oleh sabut kepala yang dibakar) dengan diiringi menbaca doa oleh dukun bayi. Sampai bayi tertidur di dalam ayunan, ini menandakan prosesi turun mandi bagi sang bayi telah selesai. Setelah prosesi turun mandi selesai prosesi akikah berlangsung di sinilah proses penyembelihan hewan kambing atas rasa syukur kepada Allah SWT atas kelahiran anak. Dan daging kambing tersebul di masak oleh tuan ruman untuk di hidangkan pada masyarakat setempat. Setelah masyarakat setempat menyantap hidangan dari tuan rumah proses terakhir dari akikah adalah si bayi di do'akan agar mendapat keselamatan sepanjang hidupnya sebagai tanda syukur kepda Allah, setelah pembacaan do'a orang tua sang bayi memperkenalkan nama bayi kepada masyarakat yang datang dalam prosesi akikah dan mulai saat itu bayi resmi memiliki nama yang sudah di sematkan oleh orang tua nya.

Tidak adanya sungai yang dapat digunakan untuk turun mandi menyebabkan banyaknya kegiatan- kegiatan dan unsu-runsur dalam prosesi turun mandi mulai berubah bahkan ada yang sudah hilang. Seperti tempat prosesi turun mandi yang tidak dilakukan disungai melainkan didepan rumah dengan air secukupnya. Perubahan tempat tersebut menghilangkan kegiatan menghanyutkan bara kayu ke sungai. Namun lain halnya dengan yang terjadi pada saat sekarang, sekitar tahun 2005 tradisi ini sudah hampir punah (hilang) di karenakan faktor alam yang mana hampir seluruh sungai di daerah ini sudah tercemar akibat aktivitas tambang emas. Akan tetapi tradisi ini masih ada dilakukan pada saat sekarang, namun pelaksanaanya tidak di sungai lagi tatapi didepan rumah dan tata caranya pun sudah berbeda, tradisi ini tidak semeriah dulu, yang dulunya tradisi turun mandi bayi ini ditunggu-tunggu oleh anak kecil sekarang tradisi ini cuma disaksikan oleh keluarga dan orang disekitar rumahnya. Tidak dapat dipungkiri bahwa kemajuan zaman hari ini secara lansung maupun tidak lansung memberikan dampak negatif terhadap kehidupan kita dalam kerangka adat istiadat, banyak terjadi distori sejarah, salah interpretasi terhadap nilai-nilai ada yang telah menjadi bagian yang tidak terpisahkan dalam kehidupan kita termasuk turun mandi bayi. Para ninik mamak merasakan akan kepunahan dan 


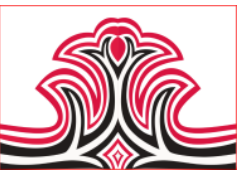

menyelewengnya tradisi ini dari tata cara yang dilakukan oleh para leluhur terhadulu.

\section{3).Proses Akikah Setelah Turun Mandi}

Akikah berarti menyembelih binatang ternak berkenaan dengan kelahiran, sebagai bukti rasa syukur kepada Allah Swt, dengan syarat-syarat tertententu. Menurut sunah Rasulullah Saw, anak yang lahir lakilaki disembelihkan dua ekor kambing. Apabila anak yang lahir perempuan, disembelih satu ekor kambing. Kambing syarat akikah di atas di sembelih dan di masak oleh tuan rumah dan di hidangkan untuk para tamu yang hadir. Prosesi akikah ini sangat penting dan di wajibkan bagi umat muslim, karena sesuai dengan syariat islam dan melaksanakan sunah rasulullah yang didalamnya terkandung hikmah dan manfaat ( $\mathrm{T}$. Ibrahim dan H. Darsono 2013:13).

\section{KESIMPULA DAN SARAN}

\section{Kesimpulan}

Tradisi turun mandi atau Bacungak yang dilakukan masyarakat Desa Pasar Baru Kecamatan Pangean adalah salah satu tradisi yang sudah ada sejak zaman nenek moyang dan masyarakat masih mempertahankan tradisi tersebut sampai saat ini, tradisi Bacungak ini merupakan salah satu tradisi kelahiran dan merupakan kearifan lokal dari masyarakat setempat kenapa disebut kearifan lokal karena tradisi ini merupakan salah satu tanda pengenal bahwa setiap bayi yang lahir di Desa Pasar Baru harus Terlebih Dahulu di Turun Mandi setelah itu baru diperbolehkan keluar rumah dan juga masyarakat juga sudah mengetahui nama dari sang bayi tersebut.

Setiap orang yang melaksanakan tradisi turun mandi bayi harus melalui beberapa tahap yaitu: Tahap perlengkapan tradisi turun mandi bayi, Tahap penentuan lokasi pelaksanaan turun mandi bayi, Tahap proses berjalannya tradisi turun mandi bayi. Perubahan di kategorikan masih tahap sedang di karenakan dari beberapa unsur perubahan cenderung hanya beberapa bagian. Perubahan pada unsur peralatan, proses-proses pelaksanaan. Semua unsur tersebut sudah mengalami pergeseran dan perubahan mengarah pada perubahan positif. Tradisi turun mandi bayi mengandung nilainilai budya dan merupakan budaya masyarakat kecamatan pangean, mempunyai fungsi adat istiadat dan social.

\section{Saran}

Bagi pemuka adat atau lembaga agama, sebaiknya memberikan sosialisasi kepada masyarakat mengenai tradisi turun mandi bayi terutama generasi muda agar tertarik dan berminat, berpatisipasi serta peduli
Gorga Jurnal Seni Rupa

Volume 08 Nomor 02 Juli-Desember 2019 p-ISSN: 2301-5942 | e-ISSN: 2580-2380

terhadap kebudayaan yang telah menjadi tradisi tersebut. Sosialisasi ini dapat berupa cerita, sejarah serta norma-norma dan nilai-nilai sosial Bagi instansi yang berada di kecamatan pangean agar berupaya untuk selalu melestarikan budaya yang telah ada dan mempromosikan kepada pemuda-pemuda setempat guna agar budaya tersebut tetap dilestarikan dan mempunyai manfaat bagi masyarakat banyak. Untuk masyarakat pangean khususnya, agar selalu menjalankan tradisi ini, karena tradisi turun mandi bayi ini tidak hanya warisan budaya luhur saja. Tradisi ini merupakan sejarah panjang di Kecamatan Pangean, dimana kita harus menjunjung tinggi sejarah awal dan budaya kita, karena budaya menunjukakan bangsa.

\section{DAFTAR RUJUKAN}

Koentjaraningrat. (2009). Pengantar Pendidikan.: Jakarta. PT. Rineka Cipta.

Koentjaraningrat. (2010). Pengantar Antropologi 1: Jakarta. PT. Rineka Cipta.

Hamidy UU. (2009). Masyarakat Adat Kuantan Singingi. Pekanbaru: Bilik Kreatif Press.

Marcelina, Shella. (2015) Tradisi Tarea-Rea dan Tarea-Rea Dalam Pertunjukan Drama Di Nagari Koto Gaek Guguak Kabupaten Solok. Program Pascasarjana. Universitas Negeri Padang. Padang.

Daryusti. (2010). Lingkaran Lokal Genius dan Pemikiran Seni Budaya. Yokyakarta: Cipta Media.

Darsono H, Ibrahim T. (2013). Penerapan fikih karakter bangsa. Solo: PT. Tiga Serangkai Pustaka Mandiri. 